\title{
Optimasi Pengelolaan Waduk Pondok Ngawi Jawa Timur
}

\author{
Hendro Susilo \\ Program Studi S1 Teknik Sipil, Universitas Merdeka Madiun, Jl. Serayu 79, Madiun, 63133 \\ E-mail: hendrosusilo1402@gmail.com
}

\begin{abstract}
Pondok Reservoir is one of the smaller reservoirs built in Bengawan Solo River Basin, located in Kali Dero, Gandong Village, Bringin District, Ngawi District, with a puddle of $3.6 \mathrm{~km} 2$ and $32.9 \mathrm{~km} 2$ of drainage area. The total reservoir volume is 25,233 MCM and the effective dams volume is 22,333 MCM. The reservoirs are used to irrigate 3.596 Ha of irrigated rice fields which are distributed through four weirs, namely Dero weir, Sambiroto dam, Plesungan dam, and Padas dam. The results showed that selected crops were rice and maize, while to obtain maximum annual agricultural benefit benefit can be done with the initial period of planting for the first planting season is the third week of November, which has annual net benefit value of agriculture of Rp. $10,797,000,000$. Through continuous water supply, the optimal planting area for each planting season is the first planting season in the third week of November with rice plant of 2877 ha and 719 ha of maize; the second growing season in the third week of March with rice plants 1216 ha and 1216 ha of maize; third planting season in the third week of July with 402 ha of corn. Percentage of planted area from available land per planting season is: first planting season is $100 \%$, second planting season is $67,63 \%$ and planting season is $11,18 \%$, so planting intensity is $178,8 \%$.
\end{abstract}

Keywords —: irrigation; optimization; early planting; net benefit.

\section{PENDAHULUAN}

Waduk Pondok adalah salah satu diantara waduk - waduk kecil yang dibangun di DAS Bengawan Solo, terdapat di Kali Dero , Desa Gandong, Kecamatan Bringin,Kabupaten Ngawi dengan luas genangan 3,6 km2 dan luas pengaliran 32,9 km2. Fungsi utama Waduk Pondok bagi masyarakat adalah penyediaan air irigasi, dan dapat dimanfaatkan untuk perikanan juga pariwisata domestik. Volume waduk total adalah $25.232 .857 \mathrm{~m} 3$ dan volume waduk efektif adalah 22.332.857 m3. Tampungan waduk dimanfaatkan untuk mengairi sawah seluas 3596 Ha yang dialirkan melalui empat bendung, yaitu : bendung Dero, bendung Sambiroto, bendung Plesungan,dan bendung Padas.

Setelah pengoperasian waduk yang dimulai pada tahun 1996, kebutuhan air irigasi dapat dicukupi. Isu yang berkembang adalah air sudah tidak mencukupi kebutuhan air irigasi sehingga dimusim kemarau lahan sawah banyak bero. Kondisi tersebut menyebabkan petani menggunakan sumur pompa untuk mengairi sawahnya.

Tujuan utama dalam penelitian adalah untuk mengetahui cara pengaturan air waduk yang optimal untuk memenuhi kebutuhan air irigasi di DI.Waduk Pondok. Dengan optimasi linear programming dan regresi non linear nantinya dapat diketahui cara untuk mendapatkan net benefit pertanian maksimal yang diperoleh selama satu tahun, luas lahan sawah terairi secara optimal, jenis tanaman terpilih, periode awal tanam terpilih MT 1, dan intensitas tanam yang tercapai.

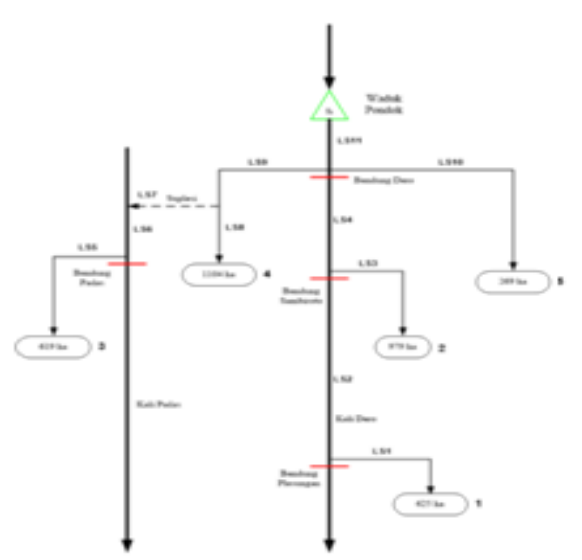

Gambar 1.Sistem Jaringan Irigasi DI Waduk Pondok

Penelitian-penelitian yang terkait diantaranya dilakukan pada tahun 2015 yaitu melakukan optimalisasi pola operasi waduk untuk memenuhi kebutuhan energi pembangkit listrik tenaga air. Penelitian tersebut dilakukan di Waduk Wonogiri. Metode yang digunakan penelitian tersebut yaitu menggunakan simulasi pola operasi waduk model stokastik dengan solver evolutionery. 
Menggunakan metode tersebut, didapatkan hasil yaitu berupa peningkatan 22,98\%. Sehingga dapat disimpulkan waduk memiliki prosentase kendalan sebesar 100\% (Samosir, dkk, 2015).

Selanjutnya penelitian dilakukan oleh Mariana, dkk dengan membuat model perkiraan debit air untuk optimalisasi pengelolaan Waduk Saguling di Kaskade Citarum. Penelitian ini membandingkan model bangkitan debit inflow dengan metode korelasi spasial antara hujan dan debit dengan metode diskrit Markov. Hasil yang didapatkan diantaranya nilai kolerasi spasial sebesar 0,86 dan sebesar 0,804 menggunakan metode disktrit Markov. Tetapi hasil optimasi memberikan nilai sebesar 0,940 dengan model kontinu, dan sebesar 0,852 dengan metode disktrit Markov (Marselina, dkk, 2017).

Di tahun 2018 terdapat penelitian tentang optimasi pemanfaatan air Embung Kasih untuk domestik dan irigasi tetes. Metode yang digunakan adalah Metode Generalized Reduce Gradient (GRG). Dimana metode tersebut dapat digunakan untuk mengoptimalkan penggunaan air embung. Hasil yang didapatkan pada penelitian ini diantaranya air embung dapat digunakan 454 orang domestik dan melakukan irigasi tetes seluas 1 hektar. Untuk tingkat keandalan operasi sebesar 78,57\% (Ginting, dkk, 2018).

\section{METODE PENELITIAN}

Adapun langkah pengerjaan dalam penelitian optimasi pengelolaan Waduk Pondok terdiri dari :

1. Pengumpulan data

Data sekunder yang digunakan dalam penelitian meliputi data pertanian berupa: pola dan jadwal tanam existing, komoditas pertanian, produksi, harga satuan produksi, biaya produksi, dan quota distribusi luas tanam; data di waduk berupa data hidrologi, klimatologi, kurva persamaan hubungan antara volume, luas dan elevasi waduk; data di lahan pertanian berupa data hidrologi, klimatologi, skema jaringan irigasi, dan luas lahan pertanian yang dilayani

2. Cek water balance antara ketersediaan air dengan kebutuhan air.

Tujuan utama dilakukan cek water balance adalah untuk membuktikan permasalahan yang ada di lapangan. Cek water balance dilakukan dengan membandingkan potensi ketersediaan air yang dapat dimanfaatkan dengan kebutuhan air yang harus dipenuhi sesuai dengan jenis dan pola tanam existing.

3. Penggunaan linear programming untuk membantu perhitungan optimasi.

Tujuan optimasi linearprogramming adalah untuk memperoleh net benefit tahunan maksimal pertanian selama satu tahun, luas lahan sawah optimal, serta intensitas tanam dengan melakukan 4 variasi awal MT 1, yaitu Oktober 2, November1, November 2, dan Desember 1.

\section{III.HASIL DAN PEMBAHASAN}

\section{A. Kondisi Net Benefit Pertanian Existing}

Hasil optimasi linear programming untuk masing - masing variasi periode awal tanam MT 1 adalah sebagai berikut :

a. Awal tanam MT 1 Oktober 2

Dari analisis menggunakan solver untuk periode awal tanam MT 1 Oktober 2 diperoleh hasil net benefit maksimal pertanian tahunan sebesar Rp. 9.379.000.000 dengan luas tanam adalah MT 1 untuk tanaman padi seluas 1535 ha dan tanaman jagung seluas 592 ha, MT 2 untuk tanaman padi dan jagung seluas 1771 ha, MT 3 untuk tanaman jagung seluas 315 ha, sehingga diperoleh nilai intensitas tanam sebesar $166,41 \%$.

b. Awal tanam MT 1 November 1

Dari analisis menggunakan solver untuk periode awal tanam MT 1 November 1 diperoleh hasil net benefit maksimal pertanian tahunan sebesar Rp. 9.840.000.000 dengan luas tanam adalah MT 1 untuk tanaman padi seluas 2682 ha dan tanaman jagung seluas 719 ha, MT 2 untuk tanaman padi dan jagung seluas 1091 ha, MT 3 untuk tanaman jagung seluas 146 ha, sehingga diperoleh nilai intensitas tanam sebesar $159,36 \%$.

c. Awal tanam MT 1 November 2

Dari analisis menggunakan solver untuk periode awal tanam MT 1 November 2 diperoleh hasil net benefit maksimal pertanian tahunan sebesar Rp. 10.797.000.000dengan luas tanam adalah MT 1 untuk tanaman padi seluas 2877 ha dan tanaman jagung seluas 719 ha, MT 2 untuk tanaman padi dan jagung seluas 1216 ha, MT 3 untuk tanaman jagung seluas 402 ha, sehingga diperoleh nilai intensitas tanam sebesar 178,81\%.

Secara grafik, hasil analisis water balance untuk periode awal tanam MT 1 November 2 dapat dilihat seperti dalam Gambar 2 berikut ini. 


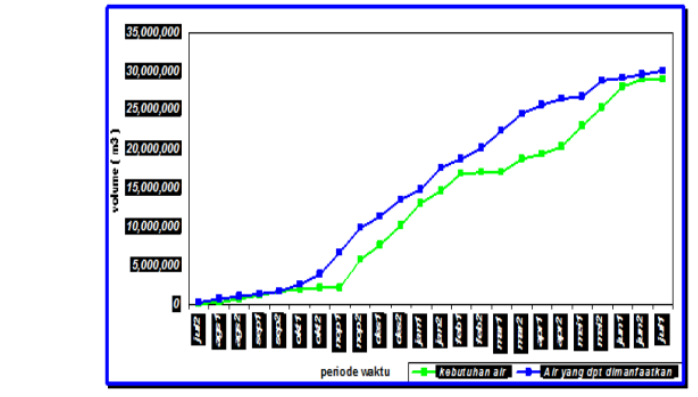

Gambar 2. Water balance periode awaltanam MT 1 November 2 secara optimal

Sedangkan muka air storage waduk Pondok sesuai dengan periode awal tanam MT 1 November 2 dapat dilihat seperti dalam Gambar 3 berikut.

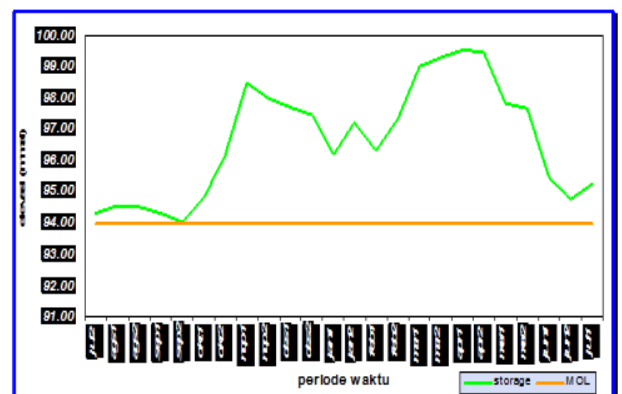

d. Awal tanam MT 1 Desember 1

Gambar 3. Muka air storage waduk periode awal tanam MT 1 November 2

Dari analisis menggunakan solver untuk periode awal tanam Desember 1 diperoleh hasil net benefit maksimal pertanian tahunan sebesar Rp. 9.736.000.000 dengan luas tanam adalah MT 1 untuk tanaman padi seluas 2877 ha dan tanaman jagung seluas 719 ha, MT 2 untuk tanaman padi dan jagung seluas 778 ha, MT 3 untuk tanaman jagung seluas 440 ha, sehingga diperoleh nilai intensitas tanam sebesar $155,51 \%$.

Adapun net benefit maksimal untuk masing - masing periode awal tanam MT 1, yaitu Oktober 2, November 1, November 2, dan Desember 1 dapat direpresentasikan seperti dalam Gambar 4 berikut ini.

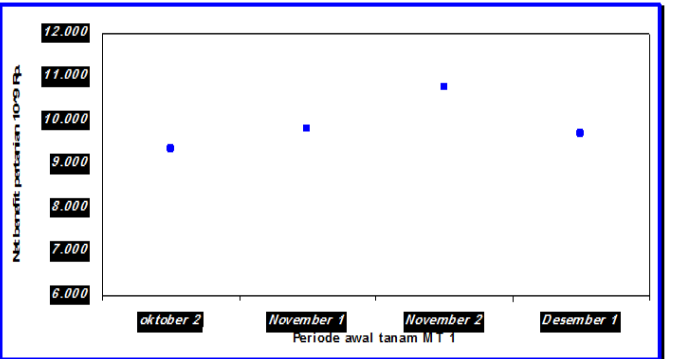

Gambar 4. Net benefit pertanian maksimal untuk masing - masing periode awal tanam MT 1

Dari grafik net benefit pertanian maksimal masing - masing periode awal tanam MT 1 diatas dapat ditarik kesimpulan bahwa net benefit pertanian maksimal terjadi pada periode awal tanam MT 1 pada November 2 dengan nilai sebesar Rp. 10.797.000.000 serta mempunyai intensitas tanam $178,81 \%$.

\section{B. Kondisi Net Benefit Pertanian Dengan Harga Tertentu}

Net benefit dicoba suatu kondisi bahwa jenis tanam tertentu akan mempunyai harga tertentu selama tiga musim tanam. Dalam kondisi ini net benefit tanaman padi untuk tiga musim tanam diambil sama dengan nilai sebesar Rp. 1.672.378/ha, sedangkan tanaman jagung untuk tiga musim tanam net benefit diambil sama dengan nilai sebesar Rp.1.194.026/ha. Kondisi net benefit pertanian dengan harga tertentu dianalisis karena pada kondisi net benefit pertanian existing untuk tanaman padi musim tanam tiga harganya sangat anjlok, sehingga akan sangat mempengaruhi hasil optimasi.

Hasil optimasi linear programming untuk masing - masing variasi periode awal tanam MT 1 adalah sebagai berikut :

a. Awal tanam MT 1 Oktober 2

Dari analisis menggunakan solver untuk periode awal tanam MT 1 Oktober 2 diperoleh hasil net benefit maksimal pertanian tahunan sebesar Rp. 8.412.000.000 dengan luas tanam adalah MT 1 untuk tanaman padi seluas 1219 ha dan tanaman jagung seluas 568 ha, MT 2 untuk tanaman padi dan jagung seluas 1798 ha, MT 3 untuk tanaman jagung seluas 453 ha, sehingga diperoleh nilai intensitas tanam sebesar 162,30\%. 
b. Awal tanam MT 1 November 1

Dari analisis menggunakan solver untuk periode awal tanam MT 1 November 1 diperoleh hasil net benefit maksimal pertanian tahunan sebesar Rp. 8.799.000.000 dengan luas tanam adalah MT 1 untuk tanaman padi seluas 2798 ha dan tanaman jagung seluas 700 ha, MT 2 untuk tanaman padi dan jagung seluas 1142 ha, MT 3 untuk tanaman jagung seluas 9 ha, sehingga diperoleh nilai intensitas tanam sebesar $161,04 \%$.

c. Awal tanam MT 1 November 2

Dari analisis menggunakan solver untuk periode awal tanam MT 1 November 2 diperoleh hasil net benefit maksimal pertanian tahunan sebesar Rp. 9.805.000.000 dengan luas tanam adalah MT 1 untuk tanaman padi seluas 2877 ha dan tanaman jagung seluas 719 ha, MT 2 untuk tanaman padi dan jagung seluas 1279 ha, MT 3 untuk tanaman jagung seluas 393 ha, sehingga diperoleh nilai intensitas tanam sebesar 182,06\%.

d. Awal tanam MT 1 Desember 1

Dari analisis menggunakan solver untuk periode awal tanam Desember 1 diperoleh hasil net benefit maksimal pertanian tahunan sebesar Rp. 8.397.000.000 dengan luas tanam adalah MT 1 untuk tanaman padi seluas 2877 ha dan tanaman jagung seluas 719 ha, MT 2 untuk tanaman padi dan jagung seluas 768 ha, MT 3 untuk tanaman jagung seluas 440 ha, sehingga diperoleh nilai intensitas tanam sebesar $154,95 \%$

Dari net benefit pertanian maksimal masing - masing periode awal tanam MT 1 diatas dapat ditarik kesimpulan bahwa net benefit pertanian maksimal terjadi pada periode awal tanam MT 1 pada November 2 dengan nilai sebesar Rp. 9.805.000.000 serta mempunyai intensitas tanam 182,06\%.

\section{Kondisi Dengan Skala Prioritas}

Prinsip pengerjaan adalah dengan skala prioritas areal sawah terdekat dari waduk yang mampu dilayani. Dari hasil analisis, waduk mampu melayani areal sawah terdekat seluas 2352 ha yang terdiri dari DI. Dero seluas 1373 ha dan DI. Sambiroto seluas 979 ha. Sedangkan jenis tanam per musim tanam disesuaikan dengan kondisi existing, yaitu MT 1 ditanami padi, MT 2 ditanami padi, serta MT 3 ditanami jagung.

Hasil analisis untuk masing - masing variasi periode awal tanam MT 1 dengan skala prioritas adalah sebagai berikut :

a. Awal tanam MT 1 Oktober 2

Dari analisis menggunakan skala prioritas untuk periode awal tanam MT 1 Oktober 2 diperoleh hasil net benefit maksimal pertanian tahunan sebesar Rp. 6.273.000.000 dengan luas tanam adalah MT 1 untuk tanaman padi seluas 951 ha, MT 2 untuk tanaman padi seluas 2352 ha, MT 3 untuk tanaman jagung seluas 586 ha, sehingga diperoleh nilai intensitas tanam sebesar $108,16 \%$.

b. Awal tanam MT 1 November 1

Dari analisis menggunakan skala prioritas untuk periode awal tanam MT 1 November 1 diperoleh hasil net benefit maksimal pertanian tahunan sebesar Rp. 7.179.000.000 dengan luas tanam adalah MT 1 untuk tanaman padi seluas 2352 ha, MT 2 untuk tanaman padi seluas 1528 ha, MT 3 untuk tanaman jagung seluas 476 ha, sehingga diperoleh nilai intensitas tanam sebesar $121,15 \%$.

c. Awal tanam MT 1 November 2

Dari analisis menggunakan skala prioritas untuk periode awal tanam MT 1 November 2 diperoleh hasil net benefit maksimal pertanian tahunan sebesar Rp. 8.049.000.000 dengan luas tanam adalah MT 1 untuk tanaman padi seluas 2352 ha, MT 2 untuk tanaman padi seluas 2090 ha, MT 3 untuk tanaman jagung seluas 417 ha, sehingga diperoleh nilai intensitas tanam sebesar $135,13 \%$.

d. Awal tanam MT 1 Desember 1

Dari analisis menggunakan skala prioritas untuk periode awal tanam Desember 1 diperoleh hasil net benefit maksimal pertanian tahunan sebesar Rp. 7.071.000.000 dengan luas tanam adalah MT 1 untuk tanaman padi seluas 2352 ha, MT 2 untuk tanaman padi seluas 1477 ha, MT 3 untuk tanaman jagung seluas 457 ha, sehingga diperoleh nilai intensitas tanam sebesar $119,22 \%$.

Adapun net benefit maksimal untuk masing - masing periode awal tanam MT 1, yaitu Oktober 2, November 1, November 2, dan Desember 1 dapat direpresentasikan seperti dalam Gambar 6 berikut ini.

Net benefit pertanian maksimal masing - masing periode awal tanam MT 1 diatas dapat ditarik kesimpulan bahwa net benefit pertanian maksimal terjadi pada periode awal tanam MT 1 November 2 dengan nilai sebesar Rp. 8.049.000.000 serta mempunyai intensitas tanam $135,13 \%$.

\section{IV.KESIMPULAN}

Dari hasil analisis penelitian optimasi pengelolaan Waduk Pondok Ngawi dapat ditarik kesimpulan tersebut dibawah.

1. Dalam penelitian digunakan asumsi bahwa potensi air untuk irigasi berasal dari jumlah inflow rerata waduk Pondok dengan suplai debit minimum kali Padas. Hal ini secara teknis terdapat dua hal yang berbeda, dimana potensi air dari inflow rerata waduk bersifat regulator dan suplai debit minimum kali Padas yang bersifat given. Dari potensi air untuk irigasi tersebut, total inflow rerata waduk Pondok adalah $92.68 \%$ sedangkan suplai debit minimum kali Padas sebesar $7.32 \%$ terhadap total anggapan inflow rerata di waduk dan debit minimum kali Padas. 
2. Jenis tanam terpilih adalah tanaman padi dan jagung, sedangkan tanaman kedelai tidak dipilih karena dalam perhitungannya mengalami kerugian sehingga menghasilkan net benefit yang tidak maksimum.

3. Untuk kondisi net benefit pertanian existing, net benefit pertanian maksimal dapat tercapai dengan menerapkan periode awal tanam musim tanam pertama pada minggu ketiga bulan November yang menghasilkan nilai Rp. 10.797.000.000. Sedangkan luas lahan sawah terairi optimal adalah musim tanam pertama pada minggu ketiga bulan November dengan luas tanam untuk padi 2877 ha dan 719 ha untuk luas tanam jagung; musim tanam kedua pada minggu ketiga bulan Maret dengan luas tanam untuk padi 1216 ha dan 1216 ha untuk luas tanam jagung; sedangkan musim tanam ketiga pada minggu ketiga bulan Juli dengan luas tanam untuk jagung 402 ha. Persentase areal tanam dari lahan yang tersedia per musim tanam untuk kondisi net benefit pertanian existing adalah musim tanam pertama sebesar 100\%, musim tanam kedua sebesar 67,63\% dan musim tanam ketiga sebesar $11,18 \%$, sehingga intensitas tanam yang dicapai adalah $178,8 \%$.

4. Untuk anggapan kondisi net benefit pertanian dengan harga tertentu, net benefit pertanian maksimal dapat tercapai dengan menerapkan periode awal tanam musim tanam pertama pada minggu ketiga bulan November yang menghasilkan nilai Rp. 9.805.000.000. Sedangkan luas lahan sawah terairi optimal adalah musim tanam pertama pada minggu ketiga bulan November dengan luas tanam untuk padi 2877 ha dan 719 ha untuk luas tanam jagung; musim tanam kedua pada minggu ketiga bulan Maret dengan luas tanam untuk padi 1279 ha dan 1279 ha untuk luas tanam jagung; sedangkan musim tanam ketiga pada minggu ketiga bulan Juli dengan luas tanam untuk jagung 393 ha. Persentase areal tanam dari lahan yang tersedia per musim tanam untuk anggapan kondisi net benefit pertanian dengan harga tertentu adalah musim tanam pertama sebesar $100 \%$, musim tanam kedua sebesar 71,13\% dan musim tanam ketiga sebesar 10,93\%, sehingga intensitas tanam yang dicapai adalah $182,06 \%$.

5. Untuk kondisi dengan skala prioritas, net benefit pertanian maksimal dapat tercapai dengan menerapkan periode awal tanam musim tanam pertama pada minggu ketiga bulan November yang menghasilkan nilai Rp. 8.049.000.000. Sedangkan luas lahan sawah terairi optimal adalah musim tanam pertama pada minggu ketiga bulan November dengan luas tanam untuk padi 2352 ha, musim tanam kedua pada minggu ketiga bulan Maret dengan luas tanam untuk padi 2090 ha, sedangkan musim tanam ketiga pada minggu ketiga bulan Juli dengan luas tanam untuk jagung 417 ha. Persentase areal tanam dari lahan yang tersedia per musim tanam untuk kondisi dengan skala prioritas adalah musim tanam pertama sebesar $65,41 \%$, musim tanam kedua sebesar 58,12\% dan musim tanam ketiga sebesar 11,60\%, sehingga intensitas tanam yang dicapai adalah $135,13 \%$.

6. Dengan membandingkan ketiga metode analisis, yaitu: kondisi net benefit pertanian existing, kondisi net benefit pertanian dengan harga tertentu, serta kondisi skala prioritas, periode awal tanam musim tanam pertama yang memberikan net benefit pertanian paling maksimal adalah pada minggu ketiga bulan November.

7. Syarat minimum muka air waduk saat mulai operasi pada periode awal tanam minggu ketiga bulan November untuk kondisi net benefit pertanian existing adalah pada elevasi $+94,30 \mathrm{mmal}$; Syarat minimum muka air waduk saat mulai operasi pada periode awal tanam minggu ketiga bulan November untuk kondisi net benefit pertanian dengan harga tertentu adalah pada elevasi $+94,30 \mathrm{mmal}$; dan syarat minimum muka air waduk saat mulai operasi pada periode awal tanam minggu ketiga bulan November untuk kondisi dengan skala prioritas adalah pada elevasi $+94,41$ mmal.

8. Dari hasil analisis optimasi, muka air waduk akhir operasi lebih tinggi daripada awal operasi. Kondisi ini menunjukkan bahwa pada saat musim tanam kedua masih terdapat potensi air yang tersedia dan lahan yang bisa dikembangkan. Realita yang terjadi apabila potensi lahan dikembangkan adalah net benefit pertanian tahunan tidak maksimal, sehingga pengembangan lahan tidak perlu dilakukan.

9. Pengaturan air untuk irigasi dengan menggunakan metode optimasi mempunyai nilai lebih apabila dibandingkan dengan skala prioritas. Keunggulan metode optimasi adalah lebih menjamin pemerataan pembagian air dari areal sawah yang tersedia, diperoleh nilai intensitas tanam yang tinggi, serta net benefit pertanian yang lebih besar.

\section{DAFTAR PUSTAKA}

Anonim, (1986), Kriteria Perencanaan Bagian Jaringan Irigasi KP-01, CV. Galang Persada, Bandung.

Anonim,(2000), Dasar Perhitungan Pendahuluan Teknik Sumberdaya Air, Grup Sumberdaya Air - Laboratorium Hidraulika,Jurusan Teknik Sipil, Fakultas Teknik, Universitas Gadjah Mada, Yogyakarta.

Basak,NN, (1999), Irrigation Engineering, Tata McGraw-Hill Publishing Company Limited, New Delhi.

Ginting, S., Rahmadani, D., Indarta, A. H., (2018), Optimasi PemanfaatanAir Embung Kasih Untuk Domestik dan Irigasi Tetes, Jurnal IRIGASI, Vol.13, No.1, ISSN : 1907-5545.

Mariana, M., dkk, (2017), Model Prakiraan Debit Air dalam Rangka Optimalisasi Pengelolaan Waduk Saguling-Kaskade Citarum. Jurnal Teknik Sipil, ITB, Vol.24, No.1.

Samosir, C.S., Soetopo, W., Yuliani, W., (2015). Optimalisasi Pola Operasi Waduk Untuk Memenuhi Kebutuhan Energi Pembangkit Listrik Tenaga Air, Studi Kasus : Waduk Wonogiri, Jurnal Teknik Pengairan, Vol.6, No.1, Hal.108-115.

Sudjarwadi,(1989), Operasi Waduk, PAU Ilmu Ilmu Teknik, Universitas Gadjah Mada, Yogyakarta.

Wurbs, RA, (1996), Modelling and Analysis of Reservoir System Operations, Prentice Hall PTR, USA 